\title{
European freight vehicle running gear: today's position and future demands
}

M Hecht

Technische Universität Berlin, Fachgebiet Schienenfahrzeuge, Sekr. SG14, Salzufer 17-19, D-10587 Berlin, Germany

\begin{abstract}
The running gear of most of the rail freight vehicles in operation today tends to be built to very old designs. The running gear for new freight rolling stock and, in particular, new types of bogie must have significantly improved performance if they are to satisfy the demands of all the stakeholders associated with the railways. Improved performance in this context means reduced inspection time and brake manipulation time in marshalling yards, lower weight, lower noise emissions and lower lateral track forces. All this can be achieved by new designs of bogie running gear, at little extra first cost and at lower whole life cost.
\end{abstract}

Keywords: running gear, freight vehicles, bogies, railway brakes, bogie design, railway noise, diagnostic systems, brake blocks

\section{INTRODUCTION}

Over the past 40 years, the traffic volume (in tonne $\mathrm{km}$ ) of the rail mode of transport has remained constant, while the European freight transport market has increased almost exponentially. All growth over the last years has happened on the road, on water and in the air. The rail market share has therefore decreased dramatically.

This decline has no single cause but is due to a number of economic, political, social and technical factors:

1. The amount of large long-distance bulk flow (coal, iron ore, etc.) has decreased dramatically and major clients of the rail mode have disappeared.

2. Just-in-time production requires delivery of small consignments at frequent intervals to different sites.

3. Railway staff demand similar treatment to other employees and are no longer prepared to work antisocial hours for low wages.

Many governments and the European Commission have therefore tended to view the national railways as outdated monopolies that stifle development. The insufficiencies of today's running gear for freight vehicles can be partly blamed for these developments since they contribute to the unattractiveness of rail freight. The current low-performance running gear reduces reliability and causes long delays during the formation and inspection of trains and their handover between administrations. In addition, both

The MS was received on 31 May 2000 and was accepted after revision for publication on 6 November 2000. the ride quality of current freight vehicles and their environmental impact are unacceptable.

Another major reason for the decreasing importance of rail freight traffic is the low average transportation speed, sometimes down to $6 \mathrm{~km} / \mathrm{h}$ over long distances. This is caused not by low line speeds but by the long time spent in shunting, by complex operating control procedures and by long-winded border formalities. As a consequence of the decreasing market share, the development and general introduction of better freight vehicles are slow.

The running gear of the vast majority of Continental European freight cars is of great uniformity. There are only two major principles in wide use: self-steering wheelsets with a leaf spring suspension system [1] are normal for two-axle rolling stock, and rigid wheelset bogies with helical springs [2] are the norm for four-axle freight cars. The two types differ in running behaviour and in costs but not in acoustic characteristics.

Compared with modern passenger rolling stock and with modern locomotives, today's freight vehicles are 15$20 \mathrm{~dB}(\mathrm{~A})$ noisier. The noise reduction methods developed for other rail vehicles are hardly transferable to freight vehicles for several reasons:

(a) ratios of loaded to tare weight of 5:1 instead of a maximum of 1.5:1 for other rail vehicles,

(b) high sensitivity to additional weight,

(c) the requirement for low first cost and life cycle cost.

The author of the present paper contends that the solution must be found in a new bogie design based on low-noise technologies, taking into account the other demands. Simply replacing the cast iron brake blocks (project EUROSABOT) with other types is essential but not 
sufficient to reach the required noise reduction and to achieve the other benefits necessary to improve the performance of rail freight.

\section{PRINCIPLES OF CURRENT EUROPEAN FREIGHT VEHICLE RUNNING GEAR}

Today, there is a surprising uniformity in the running gear for freight vehicles used on European railways. Only three basic principles are in common use in Continental Europe, as shown in Fig. 1:

(a) standard single-wheelset running gear with leaf spring suspension [2, 5];

(b) steering axle bogie (type DB 642, 652, 665 and modifications $[\mathbf{1}, \mathbf{3}, \mathbf{4}])$;

(c) rigid axle bogie (Y25 and modifications $[2,3])$.

The derivatives of the Scheffel bogie, originally developed in South Africa, and the low track force bogie LTF25 [6] developed in the United Kingdom during the 1980s have not been widely adopted in Europe owing to their relatively high cost and complexity. However, the track-friendly bogie TF25 [7] created by Powell Duffryn on the basis of their experience with the LTF25 appears to be gaining market acceptance.

\subsection{Axle guidance}

The single-wheelset running gear is mainly used for twoaxle vehicles. The vehicle body is connected by swing hangers to the parabolic or parallel leaf spring of the suspension which rests on the axle box containing the roller bearings of the wheelset.

This arrangement allows the axle box to move in both the longitudinal and lateral directions as a function of the forces created at the wheel-rail interface and the wheelset inertia, limited only by the play of the axle box in the axle horns. The principle is that of a pendulum. In the longitudinal direction, the suspension hangers are inclined, whereas in the lateral direction they are vertical. This makes them stiffer in the longitudinal sense than in the lateral direction.

The parabolic spring or, more frequently, parallel leaf spring has the advantageous behaviour of load-sensitive damping. However, it is friction damping, which means that the damping is only force related and not speed related. The friction parts are open to the atmosphere. Thus, the characteristics are influenced, for instance, by humidity and dirt, while the grease can be washed out easily in heavy rain.

The principle of the single-wheelset running gear was defined as a standard in 1890 and published in reference [5], from which the drawings in Fig. 2 have been taken. However, the single-axle running gear is still being developed today. For example, the TF25SA single-axle running gear with twin coil springs and hydraulic dampers, built by Powell Duffryn, has recently been tested at speeds of $160 \mathrm{~km} / \mathrm{h}$ in Sweden.

The parabolic or parallel leaf spring suspension and motion principles of the single-axle running gear of 1890 have been adopted in bogies since about 1925 [8]. Today, the most widespread utilization of this principle is on bogie types 652 and 665, as shown in Fig. 1.

The only widely used rigid axle bogie is the Y25 bogie of French origin. Each axle box is suspended by two helical springs and rigid guides. The damping mechanism in the vertical and lateral directions is also load-sensitive friction damping. This bogie was developed from a bogie named after the 'Cie Française de Matériel de Chemin de Fer' from 1948, which had all the principles of the later Y25 [9] (Fig. 3).

The bogie designs 652 and Y25 are interchangeable under the same wagon superstructure. The steering bogie has been shown to create smaller lateral track forces and to cause less wear in tight curves [3], but it is heavier and more expensive. The rigid guided bogie is more suitable for higher speeds, and the installation of disc brakes is easier. (see Table 1).

\subsection{Noise behaviour}

With standard cast iron block brake equipment, the noise behaviour of all these types of running gear is nearly the same (see Table 1). Only two-axle wagons benefit from an improved performance of about $-2 \mathrm{~dB}(\mathrm{~A})$ because of the small number of axles per unit length and because of the more even distribution of the axles along the train length [10].

A well-known cause of poor noise performance is corrugation of the running surface, which can be caused by block brakes (see Fig. 4). As shown in reference [11], the roughness caused by block brakes is a major factor in noise generation.

\subsection{Brake system}

High rolling noise and also braking noise are not the only problems of conventional tread braking systems. This type of brake requires relatively complicated mechanical brake rigging with a large number of plain bearing joints and articulated levers, but only one brake cylinder (see Fig. 5, obtained from reference [12]).

The numerous open friction surfaces of the brake and of the running gear (see Table 1) result in high wear rates and, consequently, a high level of maintenance effort. Additionally, there is a big scatter in the wear performance and in the braking effort supplied. The scatter of wear performance was identified thanks to Deutsche Bahn's (DB) maintenance surveillance programme LARSYG [13]. This scatter prevents the achievement of a good cost benefit ratio when designing maintenance programmes 


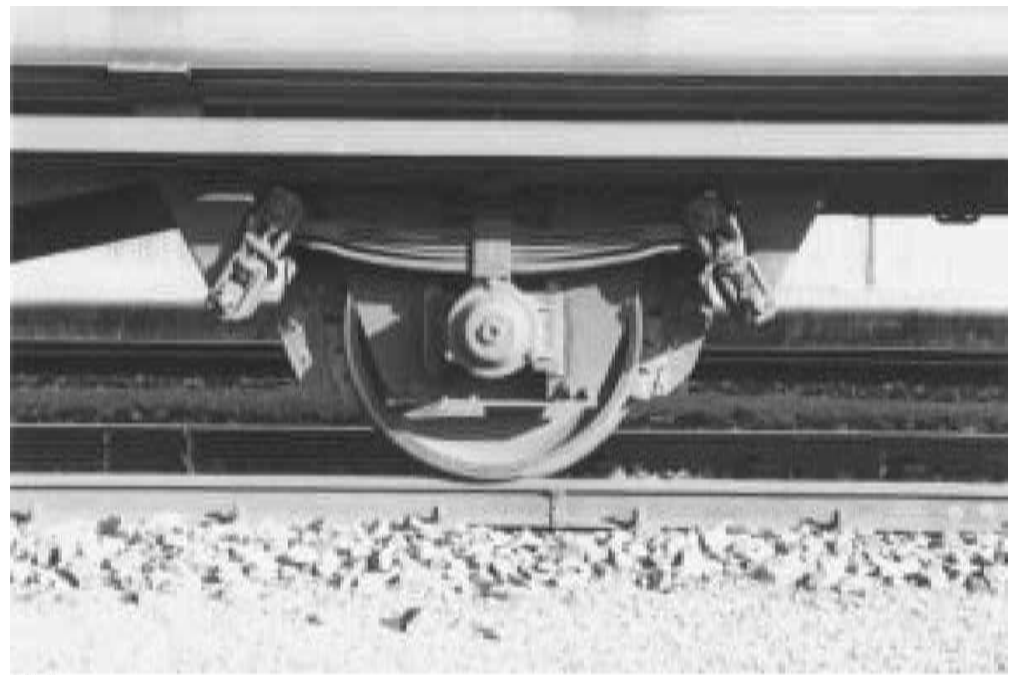

(a)

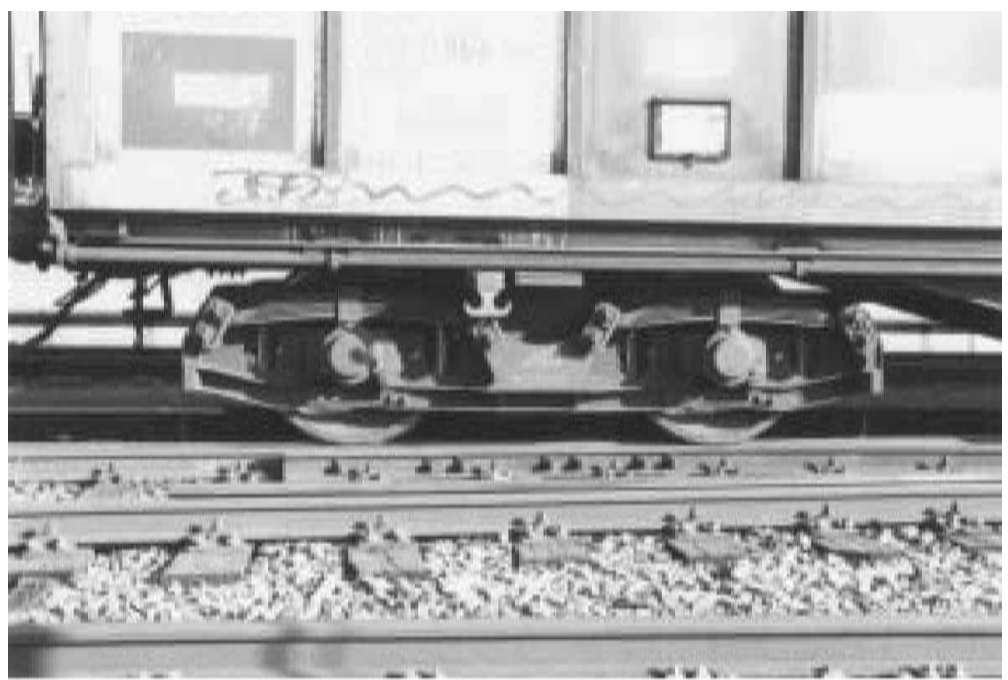

(b)

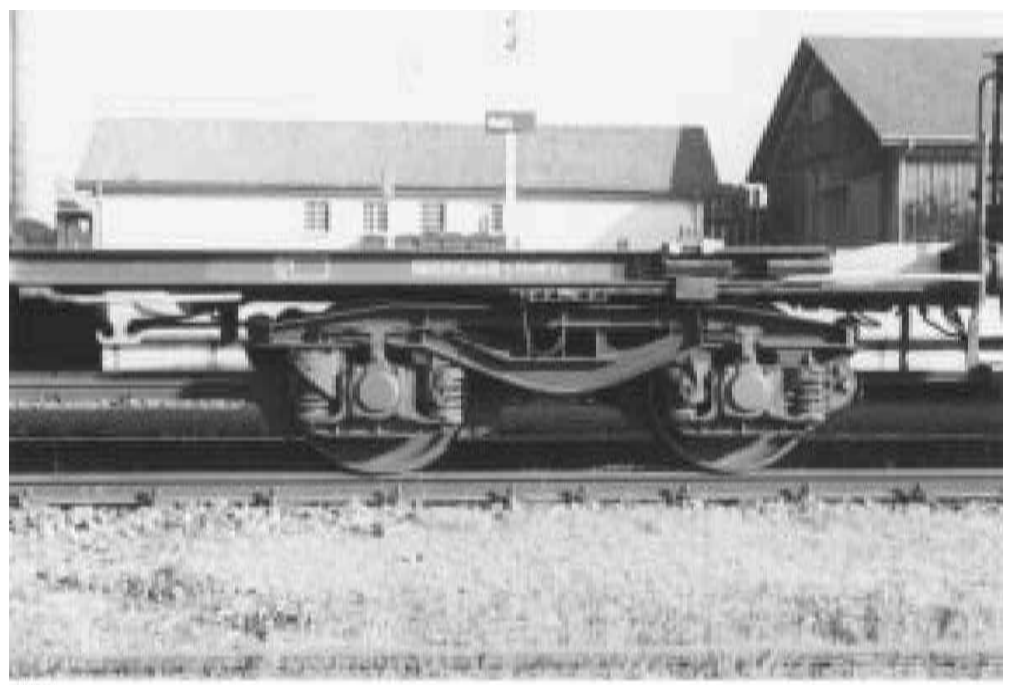

(c)

Fig. 1 Three principles of running gears: (a) single wheelset running gear; (b) radial steering axle bogie; (c) rigid axle bogie Y25 

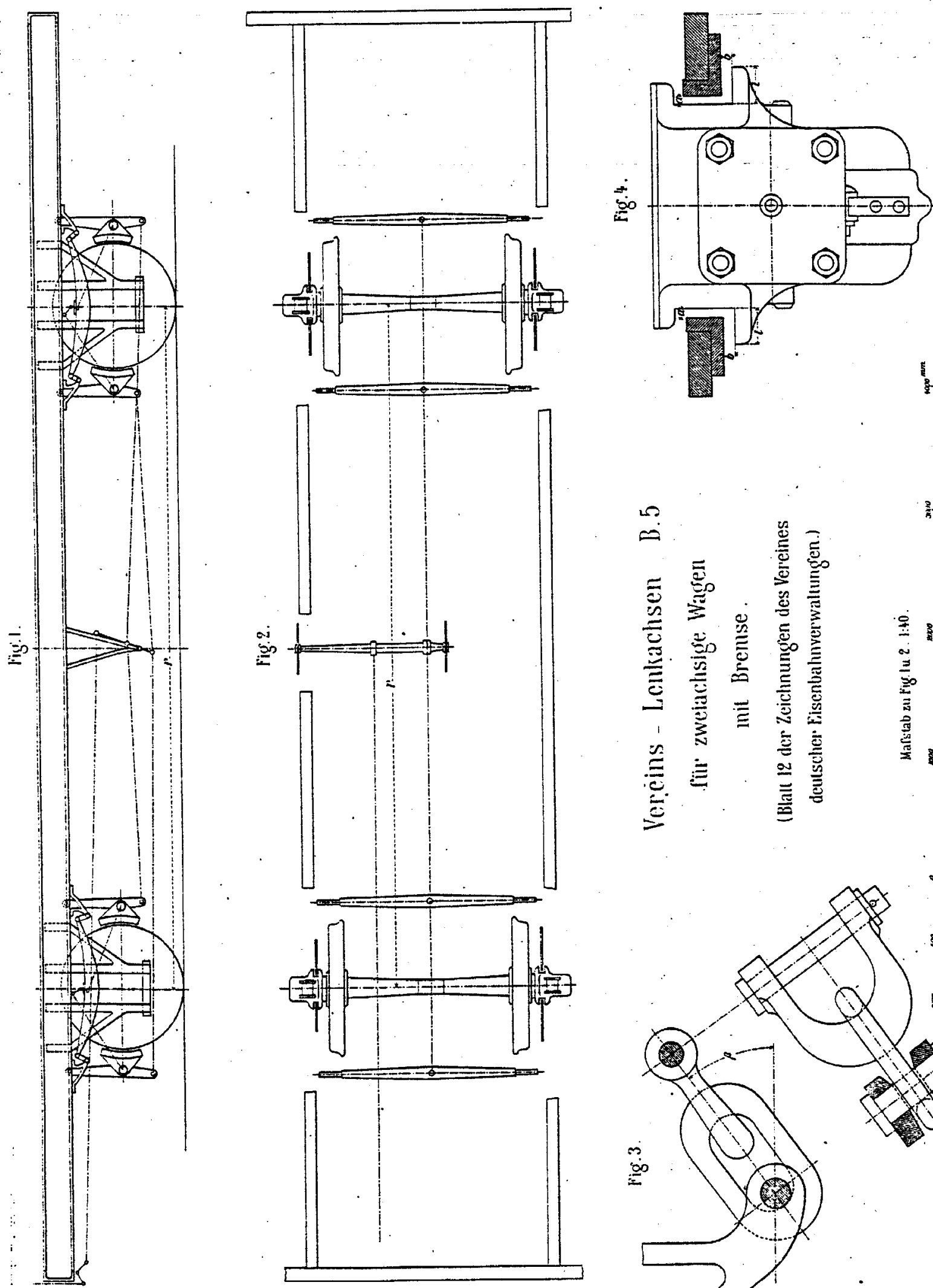

|

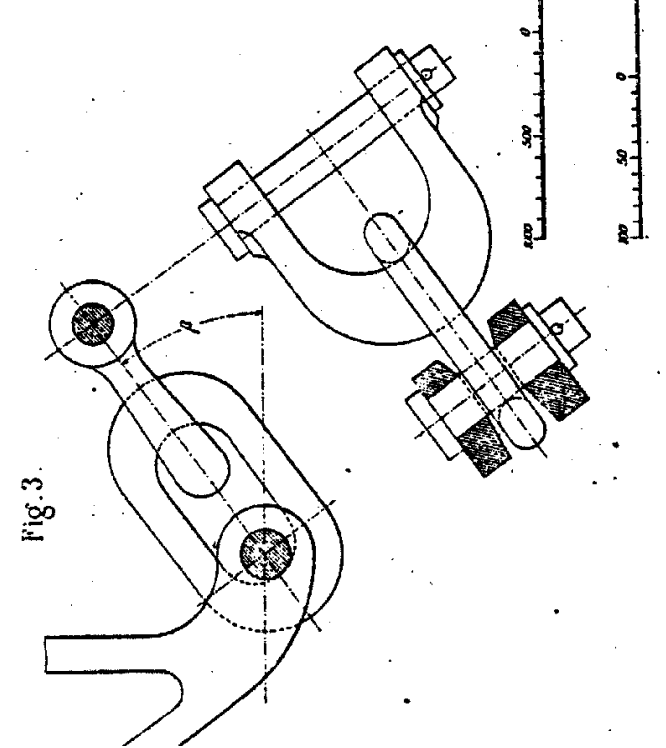




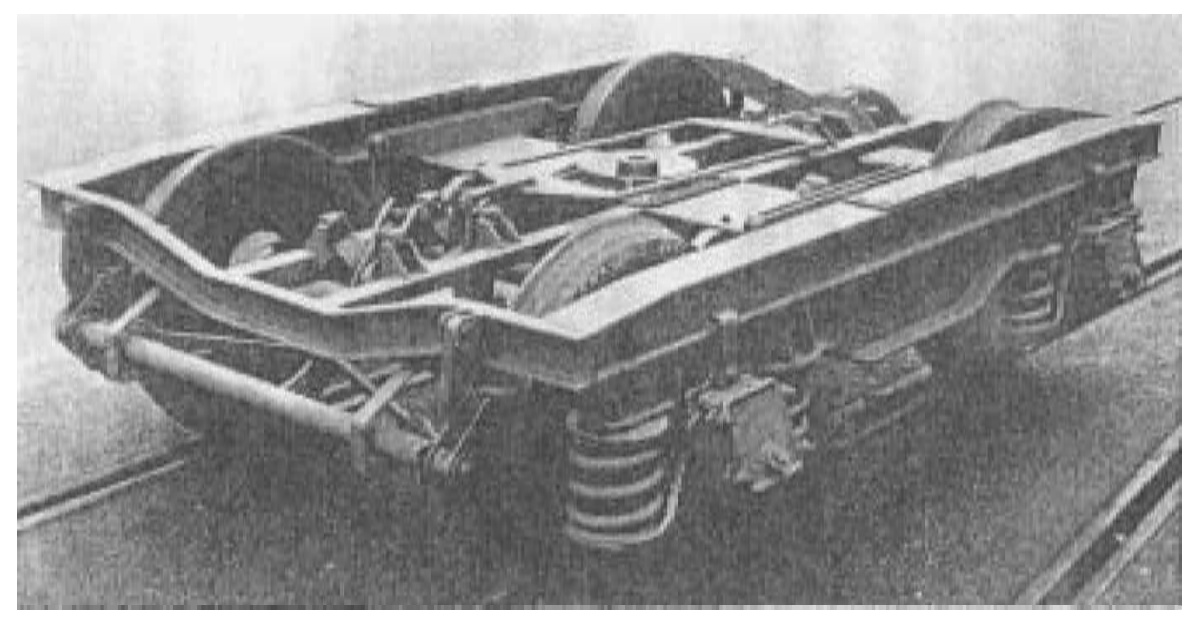

Fig. 3 First realization of Y25 principles in 1948

Table 1 Properties of the radial steering 665 bogie and rigid axle Y25 bogie

\begin{tabular}{lll}
\hline & 665 bogie & $\begin{array}{l}\text { Y25 bogie } \\
\text { (type 626) }\end{array}$ \\
\hline Weight including brake rigging (t) & 5.3 & 4.8 \\
$\mathrm{~V}_{\max }(\mathrm{km} / \mathrm{h})$ & 120 & 120 or higher \\
Wheel load $(\mathrm{t})$ & 22.5 & 22.5 \\
Brake system & Cast iron & Cast iron \\
Disc brake & Difficult & Possible \\
Noise at $7.5 \mathrm{~m}, L_{\mathrm{pfmax}}[\mathrm{dB}(\mathrm{A})]$ & $90-97(80 \mathrm{~km} / \mathrm{h})$ & $90-97(80 \mathrm{~km} / \mathrm{h})$ \\
Lateral wheel-rail forces & Lower & Higher \\
Wear on curved track & Lower & Higher \\
Slide/guide surfaces running gear & & \\
Permanent contact & 57 & 11 \\
Casual contact & 26 & 16 \\
Joints at brake levers & 51 & 47 \\
\hline
\end{tabular}

since maintenance intervention has to be scheduled early to minimize reliability problems.

The large number of parts subject to wear and the outdated design of the brake rigging also require a frequent and time consuming visual inspection procedure. As an example, the procedure for preparing the brake equipment for operation and the brake controls required before leaving a shunting yard are shown in Fig. 6 (adapted from reference [14]). The time spent in walking six times along a $700 \mathrm{~m}$ train lasts at least a complete hour even when no problem is found and where no action is required.

Each wheel is braked by four brake blocks, but only about half of the surface of the brake blocks is in contact during a particular brake application. The active surfaces of the brake blocks change from one brake application to the

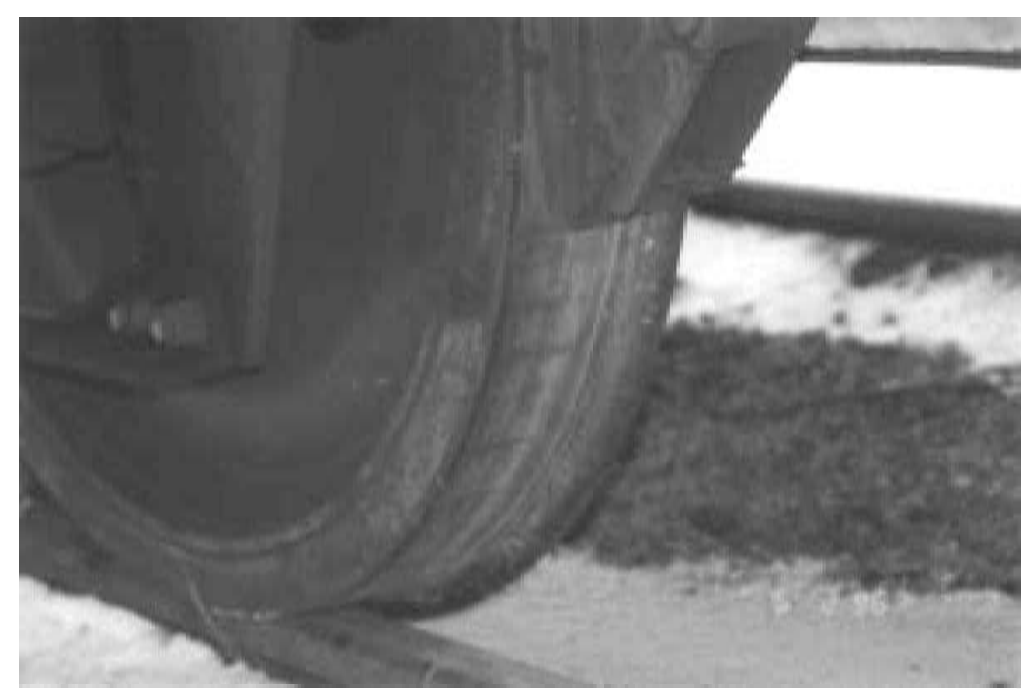

Fig. 4 Corrugation on the running surface of a cast iron block braked wheel 


\section{Anordnung der Knorr-Lastabbremsung im DB-Drehgestell für Güterwagen im SS-Verkehr}

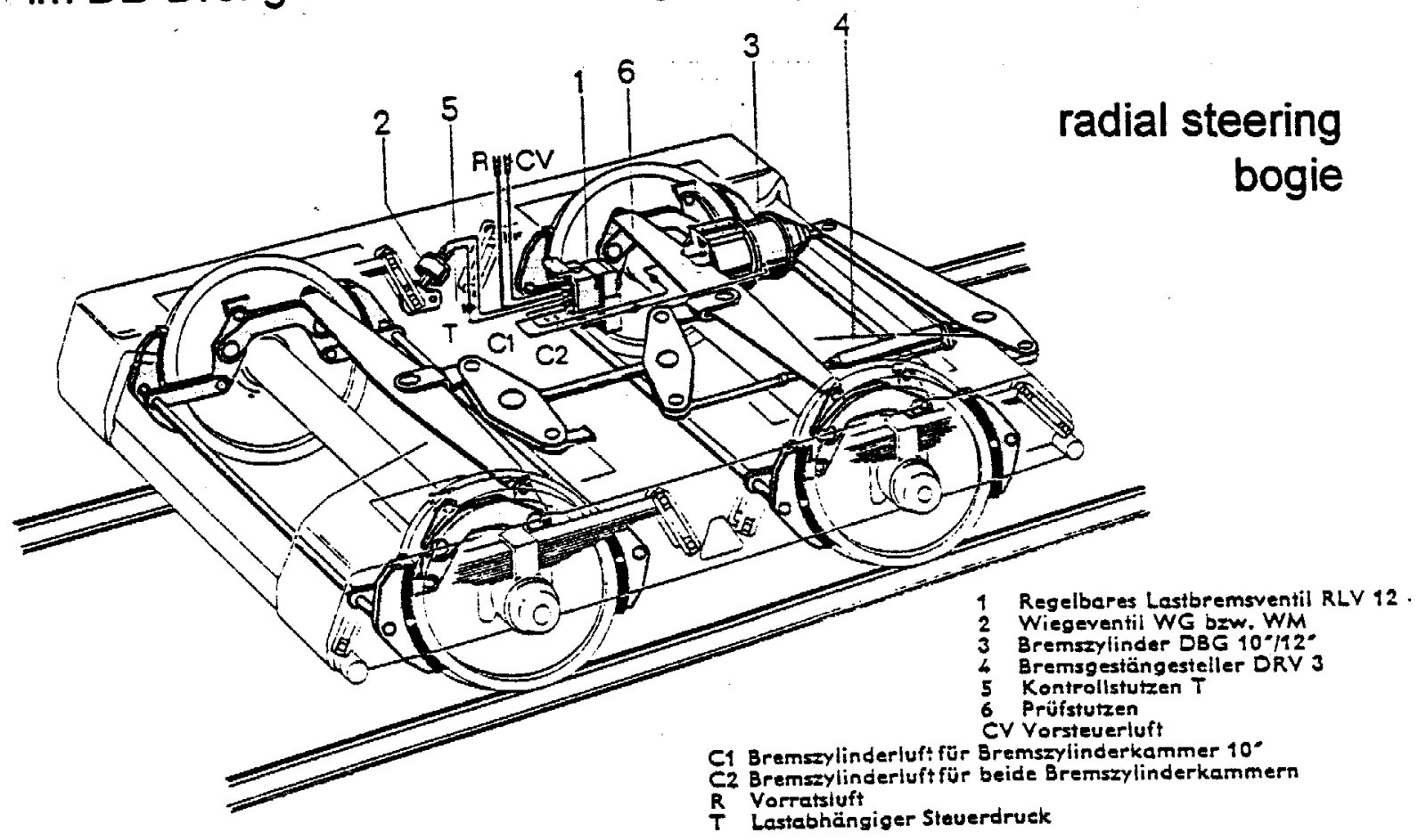

Anordnung der Knorr-Lastabbremsung im Drehgestell Y25 für Güterwagen im SS-Verkehr

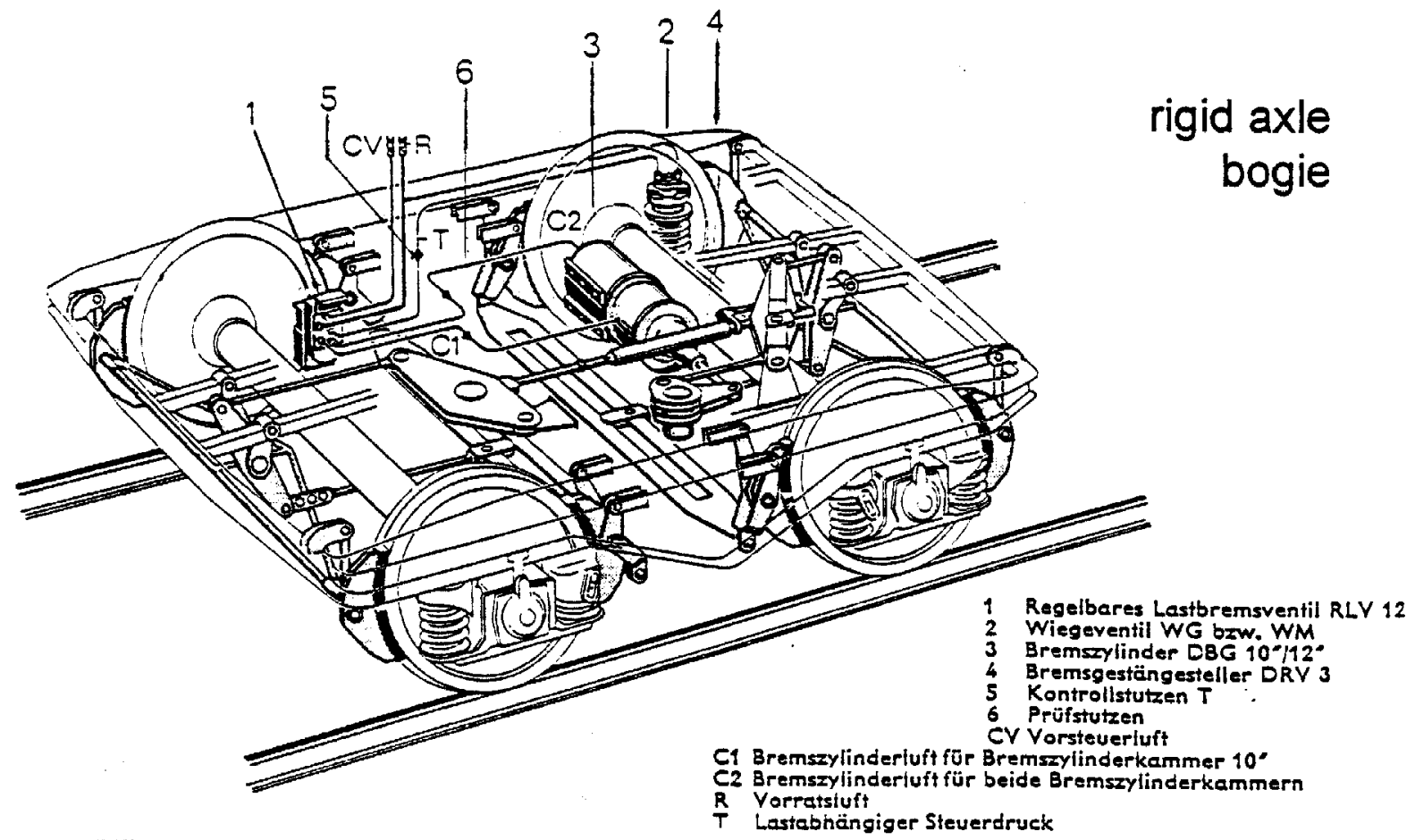

Fig. 5 Mechanical brake equipment in today's standard bogies [12] 


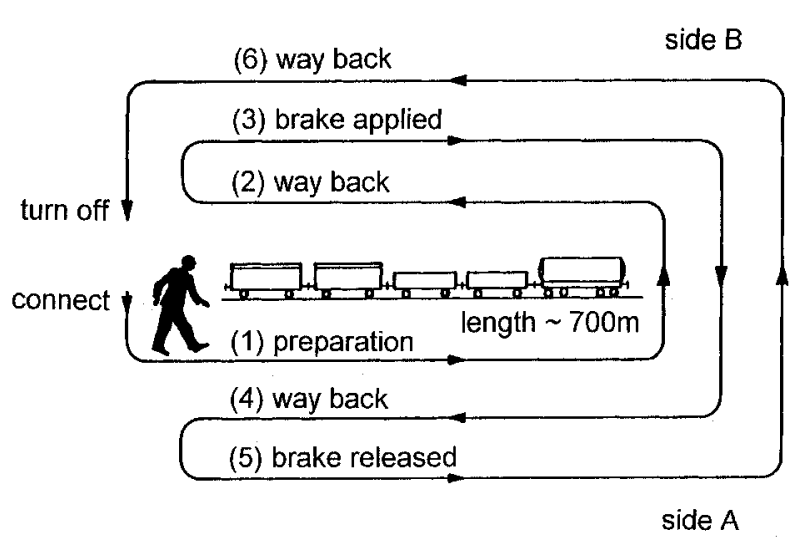

Fig. 6 Schematic for the brake preparation process in the departure track of a freight yard

next. The brake force must be very high because of the low friction coefficient between cast iron brake block and wheel. Under normal circumstances this is about $\mu=0.1$. Because of the principle of action $=$ reaction, the mechanical strength of the brake components must also be high.

The big advantage of the cast iron block brake is a certain friendliness to the wheels. This results mainly from the friction behaviour. The reduced friction level at high speeds reduces the brake force automatically, thus limiting the braking power in comparison with the linear characteristics found in other brake systems. At low speeds, the engine driver is expected to reduce the brake force by partially releasing the brake. Otherwise, the brake force could become too high and cause a strong stopping jerk.

Although the principle of the Y25 bogie has been used for 50 years and that of the radial steering running gears for more than 100 years, several improvements were made during that time $[\mathbf{3}, \mathbf{4}, \mathbf{1 5}, \mathbf{1 6}]$. Increased speed and axle weight, improved structural integrity, reduction in production costs, partly polyamide wear surfaces, etc., were realized.

\section{LEVELS OF STANDARDIZATION}

Different levels of standardization can be applied to the design of freight rolling stock, but the main objective must be to achieve a safe and cost effective circulation of the wagons throughout the whole of Europe. The following levels of standardization can be differentiated:

(a) interoperability;

(b) interchangeability: wear parts, for instance, brake blocks or pads and dampers, and all parts of the running and brake gear;

(c) standard design of freight wagons according to UIC leafet 571 (Union Internationale des Chemins de Fer).
Interoperability means that all key performance characteristics (speed capability, couplers, brake operation, derailment criteria, etc.) satisfy minimum standards, thus allowing operation of different wagons without restrictions on all routes built to UIC standards. Interchangeability standards enable the repair of wagons to be handled by any qualified workshop in a more uniform manner, for instance, by application of UIC leaflets 542 and 570 .

Until a few years ago, European railways had the objective of achieving all levels of standardization, including the acquisition of identical fleets of wagons. The intention was to obtain an easy method for mutually exchanging wagons and calculating balancing payments for different levels of use between the different railway administrations. However, the system caused great inflexibility and offered few incentives for development. As a result of the standardization effort, today's position with respect to freight vehicle running gear is characterized by a very high degree of commonality, probably the highest level of uniformity that railways have ever experienced, right from their very beginning in the early 1800 s.

\section{NEW BOGIE AND BRAKE SYSTEM DESIGNS}

There is a great demand for new types of freight vehicle running gear, particularly bogies, both in Europe and in American-influenced countries [17]. New developments result not only from noise reduction requirements but also from the demand to reduce transportation time and life cycle costs (LCCs) and to increase availability and reliability. As demonstrated in Section 1, the productivity of rail freight must become much higher if the rail market share is to increase again.

\subsection{Standardization issues}

Suitable conditions are needed to achieve this: standardization should be at the lowest possible level, that is, common performance standards to guarantee interoperability. Wear noise and track forces should be covered by track access charges and not by the imposition of detailed technical standards. This ensures a more flexible and faster development process. Also, failure handling can be solved [18].

\subsection{Bogie design issues}

From the outside, freight bogie design seems to be a very simple and not very demanding task. However, this is not so, mainly because of the immense weight difference between the empty and the loaded conditions, as shown in Fig. 7. Freight vehicle running gear has to cope with loaded/tare ratios of 2.5:1-5:1 and more. Even urban transport systems are far away from such figures. Running safety, including derailment prevention, coupling conditions and kinematic loading gauge clearance are severely 


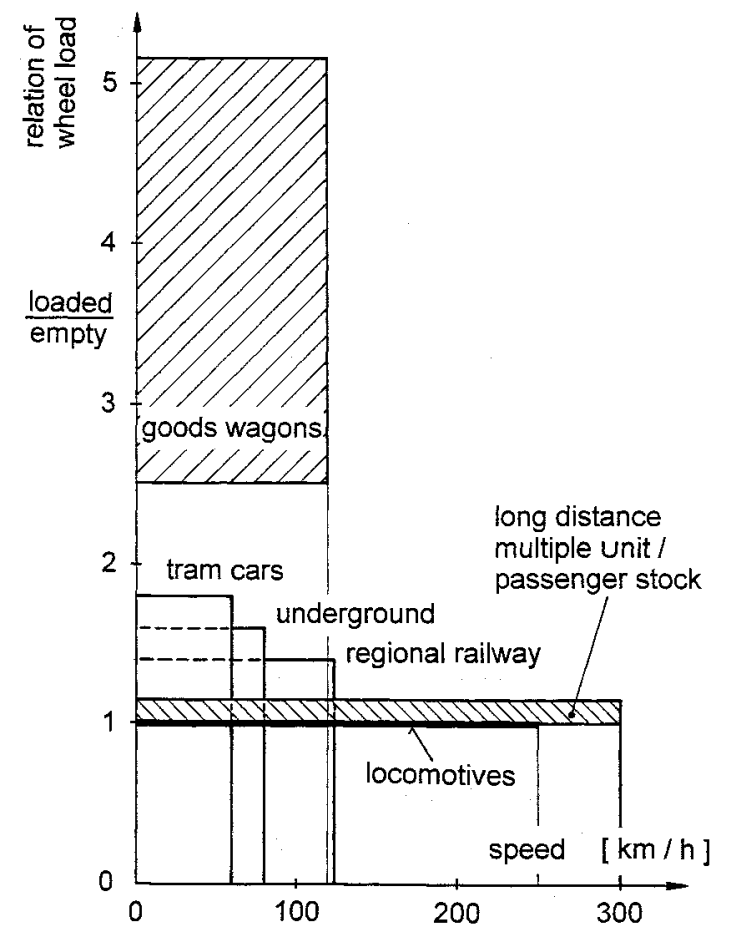

Fig. 7 Different vehicle types in relation to wheel load and speed range

affected by this demand. Braking in curves on track canted for high-speed passenger operation, in particular, poses severe problems. The design of brake systems that adjust the brake effort to the load automatically is therefore very important.

Radial steering is expected to meet today's wear and derailment requirements and also reduces curve squeal [19]. However, compromises may be necessary in order to satisfy stability requirements $[\mathbf{2 0}, \mathbf{2 1}]$.

Bogies with inside-journal axle bearings have big weight advantages. However, they need an onboard hot axle box detection or diagnosic system because hot axle box detectors (HABDs) in central Europe are designed to handle outside axle bearings only. The eutectic plug device developed in the United Kingdom by Powell Duffryn is perhaps the simplest solution to this problem since it allows venting of the brake pipe without any electronic control systems should an inside axle bearing overheat. However, this will generally lead to service disruption because the train is stopped the instant the plug melts-whether it is a real problem or a failure of the device. An electronic system installed on the vehicle (see Section 4.4) can provide both the emergency braking function and an instant location and analysis of the fault.

\subsection{Brake system issues}

Modern friction materials are of the composite or sintered types. They not only have constant friction behaviour as a function of speed but also provide much higher maximum friction levels than cast iron, up to $\mu=0.4$. The higher friction levels reduce the required brake block forces and thereby the structural requirements for the reaction forces on the bogie frame. A serious problem, though, is the high heat input loading of the wheel surfaces at high speeds. Because of the constant friction behaviour, the brake power is linearly dependent on speed and not degressive as in the case of cast iron mentioned before. To keep the brake power within certain limits, as is the case with cast iron brake blocks, the brake pressure at high speeds must be reduced by the pneumatic control equipment (Fig. 8).

A further advantage of composite and sintered materials is the wear rate, which is much lower than that of cast iron. Brake blocks made of these materials last up to five times as long as cast iron brake blocks. This not only compensates for the higher cost per brake block but also gives a high-value return by reducing the need for maintenance downtime, space for workshops and a large labour force.

The weight can also be reduced by a more suitable brake system. Composite brake blocks built into brake block units (Fig. 9) are very weight efficient because of the smaller brake forces, fewer brake units and lighter brake blocks [22]. One brake unit can replace up to four cast iron brake blocks, even on radial steering bogies. Disc brakes, whether wheel or axle mounted, have significantly higher masses and thus inertias because of the addition of the necessary brake discs.

For emergency brake purposes, a slightly reduced braking performance can be compensated for by the faster response of electrical or electronic control instead of the old pneumatic system which is limited by the wave propagation in the compressed air system. With simultaneous electronic control, the brake force in the train can be built up much faster than with pneumatic control, without the risk of creating longitudinal oscillations in the train [23].

\subsection{Electronic brake control and diagnostics}

To improve brake behaviour in normal train operation and also in shunting operation, an electrically or electronically controlled pneumatic or hydraulic brake system must be provided, for instance EBAS [6, 23]. The energy supply system and the necessary local microprocessor intelligence for the electronic brake should also be used to implement a diagnostic system to reduce maintenance and time train configuration effort.

The diagnostic system is needed to reduce the inspection time after shunting and to improve reliability. With central monitoring of freight vehicle running gear and brake equipment, a train driver can check the operational status of a $700 \mathrm{~m}$ long train in 1-2 min, thus minimizing the inspection time. With the presently available bogie designs, it is impossible to install such a diagnostic system because of the large number of friction points which cannot be monitored economically all at the same time. Such a 

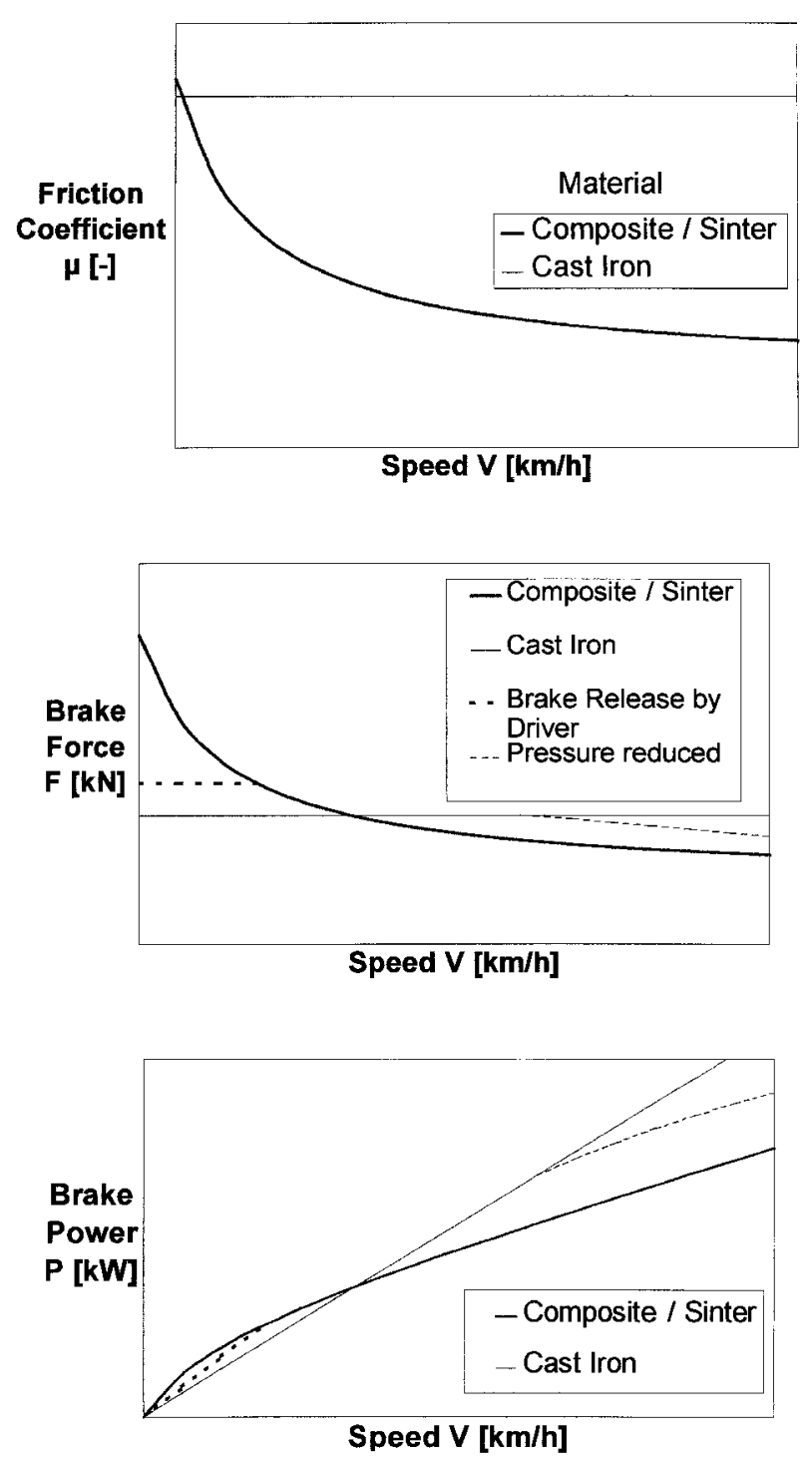

Fig. 8 Behaviour of friction materials versus speed as a function of friction coefficient, brake force and brake power

diagnostic system also reduces maintenance downtime since it allows rapid identification of faults.

\subsection{Noise issues}

The objective of reducing noise cannot be achieved simply by using a modern brake system on its own (see Fig. 10). Sophisticated acoustic design methods $[\mathbf{2 4}, \mathbf{2 5}]$ are also required if quieter vehicles are to be developed. The $80 \mathrm{~dB}(\mathrm{~A})$ limit at $80 \mathrm{~km} / \mathrm{h}$ corresponds to the recommendation of the German Umweltbundesamt for new locomotives, etc. [26].

The only currently existing valid legislation for freight vehicles in Europe is the Austrian SchLV [27] for freight cars, where a similar value of $81 \mathrm{~dB}(\mathrm{~A})$ at $80 \mathrm{~km} / \mathrm{h}$ is demanded. European ordained limits are still under development.

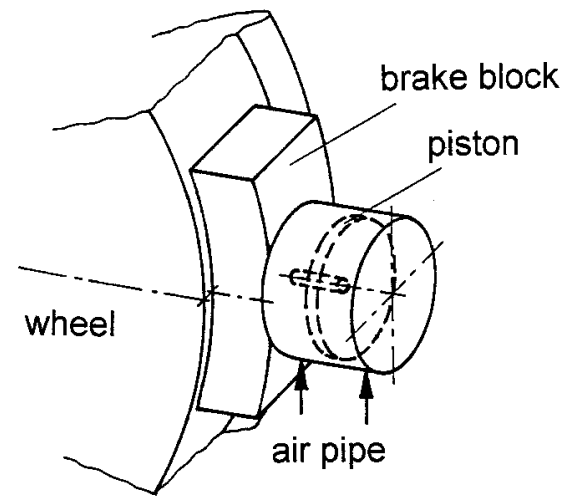

Fig. 9 Principle of a brake block unit

Many of the improvements in the noise performance of freight railways have been obtained as byproducts of introducing other technologies, such as welded rails or disc brakes. As there are many other important problem areas in the technology of rail freight vehicle running gear at present, noise reduction should not be dealt with in an isolated fashion but should be addressed in combination with all the other requirements. Since many railway administrations are currently updating their freight rolling stock, there is now an ideal opportunity to develop new systems in a holistic fashion.

\section{CONCLUSION}

The need to improve simultaneously several different features of rail freight vehicle running gear and, in particular, bogies provides an opportunity for substantial improvements in the performance of rail freight. Better control of wheelset curving reduces track forces and noise during curving. As far as stability considerations allow, the running gear should be designed to enable full radial steering. A whole life costing approach brings long-term benefit since it considers not only first costs but also maintenance requirements and the impact on other elements of the railway system.

The development and fitting of modern brake systems can also lead to reductions in noise, can reduce weight and can minimize maintenance requirements. The brake force must be automatically reduced at higher speeds to avoid overheating of wheels and should also be varied in line with the loading status of the vehicle. Electronic diagnostic equipment should not only be used to improve the availability of information for maintenance work but also be configured to reduce the time required for brake tests. Where electronic systems are installed to monitor the performance of the vehicle, they should also be used to allow cargo monitoring. 


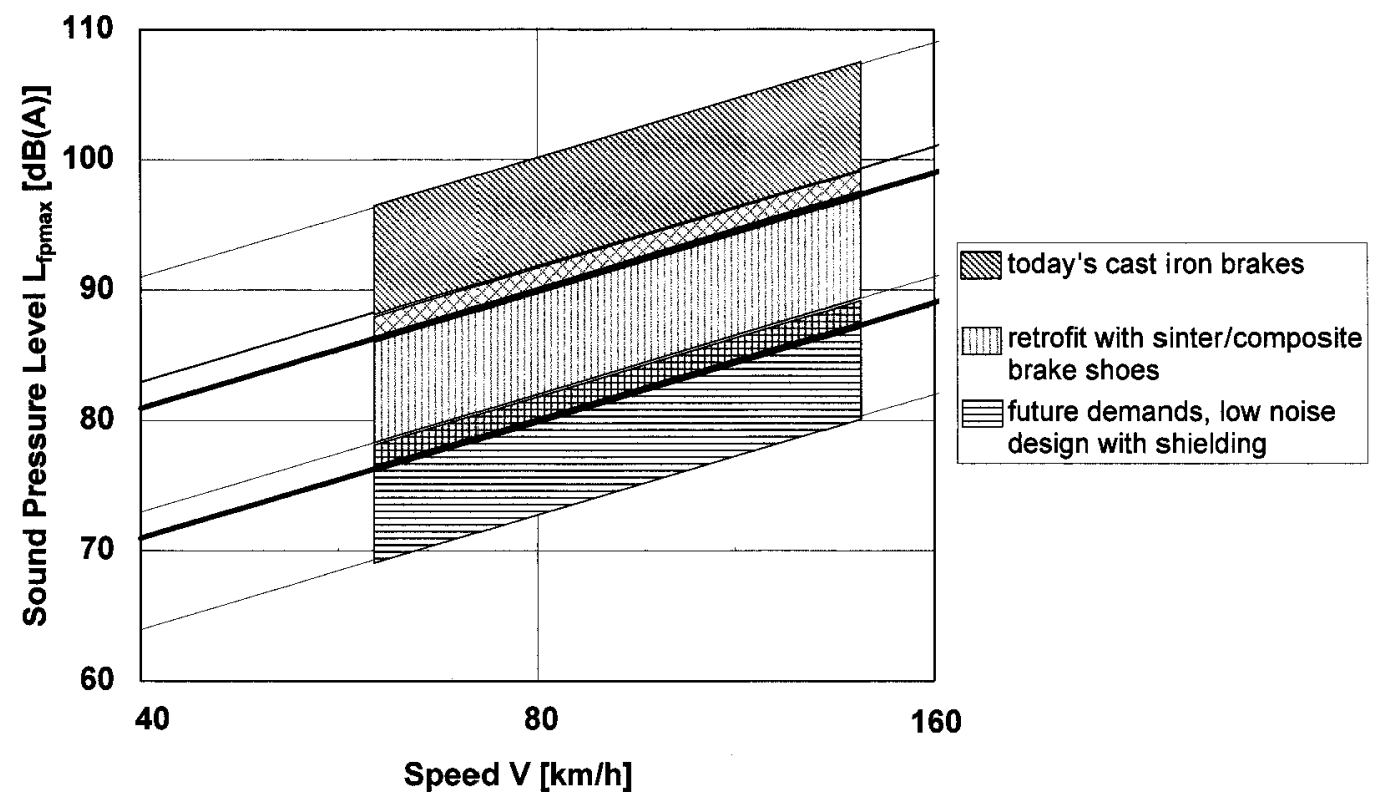

Fig. 10 Outside noise behaviour (noise during passage of train) as a function of speed and wheel surface conditioning by different brake systems

\section{REFERENCES}

1 Stichel, S. Running behavioiur of railway freight wagons with single-axle running gear. TRITA-FKT Report 1998:40, Department of Vehicle Engineering, Royal Institute of Technology, Stockholm, 1998.

2 Jendel, T. Dynamic analysis of a freight wagon with modified Y25 bogies. TRITA-FKT Report 1997:48, Department of Vehicle Engineering, Royal Institute of Technology, Stockholm, 1998.

3 von Madeyski, Th. Die Güterwagendrehgestelle Y25 und 665. Eisenbahntechnische Rundschau, 1978, 27, 713-720.

4 Müller, L and Niermeyer, W. Weiterentwickelte GüterwagenDrehgestelle der Deutschen Bundesbahn für 22,5 t Radsatzlast-wieder nach dem Lenkachsprinzip. ZEV-Glas. Ann., 1987, 111(6), 188-197.

5 Vereinslenkachsen für zweiachsige Wagen mit Bremse. Organ für Fortschritte des Eisenbahnwesens, 1890, Table 29 (Edmund Heusinger von Waldegg).

6 Gralla, D. Eisenbahnbremstechnik, 1999 (Werner-Verlag, Düsseldorf).

7 Harding, A. B. Developments of the TF25 'track-friendly' bogie. In IMechE Seminar Railtech 98, Birmingham, 1998, paper C552/046/98.

8 Rossberg, R. R. Deutsche Eisenbahnfahrzeuge von 1833 bis Heute, 1988 (VDI-Verlag, Düsseldorf).

9 Lejeune, M. and Lenoir, M. Le Bogie Y 21 A pour wagons de Merchandises de La S.N.C.F. Rev. Gen. Chemins de Fer, November 1963, 621-626.

10 Weissenberger, W. and Kurze, U. J. Experience gathered from measurements and classification of individual vehicles. In 2nd International Workshop on Abatement of Railway Noise Emissions-Freight Transport, Berlin, 1998, pp. 71-75.
11 Dings, P. C. and Dittrich, M. G. Roughness on Dutch railway wheels and rails. J. Sound and Vibr., 1996, 103-112.

12 Handbuch Knorr Bremse, 1976.

13 Seidenstücker, B. Anforderungen an die Konstruktion und Instandhaltung der Schienenfahrzeuge aus Sicht von DB Cargo. Schienenfahrzeugtagung, Dresden, 17-19 September 1997, Vol. 2, pp. 85-89.

14 Kuper, K. and Janicki, J. Bremstechnik und Bremsproben. DB-Fachbuch 3, 1996 (Eisenbahnfachverlag).

15 Müller, L. Einzelachslaufwerke für Güterwagen für hohe Geschwindigkeiten. ZEV+DET Glas. Ann., 1992, 116, 473-476.

16 Dorn, C. Innovative Güterwagen. Eisenbahningenieur, 1997, 8, 7-13.

17 Scales, B. T. Review of contemporary freight car bogie design. In IMechE Seminar on Railway Rolling Stock, 1996, pp. 97-110.

18 Hecht, M. Trendwende im Schienengüterverkehr, 2. TUBVerkehrstagung Zukunftsfähige Verkehrsentwicklung, 24 April 1997, pp. 79-85.

19 Hecht, M. Kurvenkreischen, Ursachen und Gegenmaßnahmen. Schweizer Eisenbahnrevue, 1995, (3), 103-108.

20 Scheffel, H., Smit, O. H. and von Gericke, R. E. Shear stiffer linkages for radial bogies. In Proceedings of 4th International Conference on Railway Bogies and Running Gears, Budapest, 1998, pp. 85-93.

21 Fröhling, R. D. The influence of friction wedges on the dynamic performance of three-piece self steering bogies. In Proceedings of 4th International Conference on Railway Bogies and Running Gears, Budapest, 1998, p. 95-103.

22 Glatte Räder auf glatten Schienen. Forschungs- und Technologi-Report der Deutschen Bahn AG, BahnTech 4/97, 1997, pp. 4-12.

23 Klink, D. The year of the electronic air brake. Railway Gaz. Int., February 1998, 95-99. 
24 Hecht, M. and Zogg, H. Lärmdesign moderner Triebfahrzeuge am Beispiel der Lok 2000-Familie. ZEV+DET Glas. Ann., 1995, 119, 463-472.

25 Hecht, M. Outside noise of rail-vehicles, situation and coutermeasures. In International Workshop on Noise Abatement of Railway Vehicles, 9-10 December 1996, pp. 81-92.
26 Jäcker, M. The necessity of a regulation for the noise emissions from railway vehicles. In International Workshop on Noise Abatement of Railway Vehicles, 9-10 December 1996, pp. 13-16.

27 Schienenfahrzeug-Lärmzulässigkeitsverordnung-SchLV. Bundesgesetzblattfür die Republik Österreich, Vienna, 1993. 